\title{
Development of a recombinase polymerase amplification combined with lateral flow dipstick assay for rapid and sensitive detection of bean common mosaic virus
}

\author{
Jiachao Qin ${ }^{1,2}$, Zhe Yin ${ }^{3}$, Danyu Shen ${ }^{4}$, Huatao Chen ${ }^{1}$, Xin Chen ${ }^{1,5}$, Xiaoyan Cui ${ }^{1,5^{*}}$ and Xuehao Chen ${ }^{2 *}$
}

\begin{abstract}
Bean common mosaic virus (BCMV) is one of the most widespread and damaging viruses of cultivated legumes in the world. In addition to serious yield reduction and germplasm decline, BCMV infection also makes legumes more vulnerable to other pathogens. Early diagnosis of the virus is particularly important in limiting its spread. Recombinase polymerase amplification (RPA) is a novel isothermic amplification technology. The whole reaction can be done outside the laboratory environment after the nucleic acid sample is obtained. In this study, we established a rapid and sensitive RPA combined with the lateral flow dipstick (LFD) assay for detection of BCMV, based on the conserved BCMV coat protein (CP) gene sequence. Specific primers and a probe were designed, which amplify $150 \mathrm{bp}$ CP fragments from BCMV-infected samples under a constant temperature of $37^{\circ} \mathrm{C}$ for 20 min. The end-labeled amplification products were detected by high-affinity LFD within 5 min. Sensitivity of this RPA-LFD assay was 1000 times greater than that of the conventional polymerase chain reaction (PCR) assay. Furthermore, when the primers/probe were used against related potyviruses including soybean mosaic virus (SMV), bean yellow mosaic virus (BYMV), and turnip mosaic virus (TuMV), the three potyviruses were not detected, indicating that the assay was BCMV species-specific. The RPA-LFD assay was also successfully applied for the detection of seed-borne BCMV in beans. The RPA-LFD assay has great potential application in the rapid diagnosis of BCMV in the field.
\end{abstract}

Keywords: Potyvirus, RPA, LFD, Field detection, Viral diagnosis, Phaseolus angularis, Glycine max

\section{Background}

Bean common mosaic virus (BCMV, genus Potyvirus) is a pathogen of common beans (Phaseolus vulgaris), as well as other cultivated and wild legumes (Morales 2006). Yield loss can reach $100 \%$ in severely BCMVinfected bean fields (Saqib et al. 2010; Li et al. 2014), and the virus is internationally distributed. Isolates of

\footnotetext{
* Correspondence: cxy@jaas.ac.cn; xhchen@yzu.edu.cn

${ }^{1}$ Institute of Industrial Crops, Jiangsu Academy of Agricultural Sciences/ Jiangsu Key Laboratory for Horticultural Crop Genetic Improvement, Nanjing, Jiangsu 210014, People's Republic of China

2Department of Horticulture, College of Horticulture and Plant Protection, Yangzhou University, Yangzhou, Jiangsu 225009, People's Republic of China Full list of author information is available at the end of the article
}

BCMV have been identified and characterized from different countries, including USA, India, China, Iran, South Korea, Turkey, and Australia, based on analysis of complete or partial genome sequences (Flores-Estévez et al. 2000; Saqib et al. 2005; Damayanti et al. 2008; Cui et al. 2014; Seo et al. 2015; Jang et al. 2018). BCMV is divided into strains based on host symptoms, serological relationships, high performance liquid chromatography peptide mapping, and genome sequence (Drijfhout et al. 1978; McKern et al. 1992; Mink and Silbernagel 1992; Feng et al. 2014a, 2014b; Li et al. 2016). An RT-PCRbased method combined with restriction enzyme analysis was first used to distinguish between BCMV and its

(c) The Author(s). 2021 Open Access This article is licensed under a Creative Commons Attribution 4.0 International License, which permits use, sharing, adaptation, distribution and reproduction in any medium or format, as long as you give

appropriate credit to the original author(s) and the source, provide a link to the Creative Commons licence, and indicate if changes were made. The images or other third party material in this article are included in the article's Creative Commons licence, unless indicated otherwise in a credit line to the material. If material is not included in the article's Creative Commons licence and your intended use is not permitted by statutory regulation or exceeds the permitted use, you will need to obtain permission directly from the copyright holder. To view a copy of this licence, visit http://creativecommons.org/licenses/by/4.0/ 
closest relative, bean common mosaic necrosis virus (BCMNV) (Saiz et al. 1994). Flores-Estévez et al. (2003) used RT-PCR with primers based on the viral coat protein $(C P)$ gene sequence to differentiate BCMV from BCMNV. A disadvantage of conventional RT-PCR-based assays for BCMV is their unsuitability for rapid detection in the field.

Recombinase polymerase amplification (RPA) (Piepenburg et al. 2006) has been explored for molecular detection of bacteria, fungi, and viruses. The RPA process employs three enzymes: a recombinase, a single stranded DNA-binding protein (SSB) and a strand-displacing polymerase (Piepenburg et al. 2006) to implement the amplification of a specific genome fragment. Unlike PCR-based methods, which require stringent temperature cycling, RPA reactions can be operated at a constant temperature of $37^{\circ} \mathrm{C}$, thereby avoiding the requirement of a thermal cycler. The reactions can be completed in 5-20 min depending on the starting copy number of the targeted template and the size of the amplicon. The RPA assay has been reported in diagnosis of several plant viruses, including those with DNA genomes such as wheat dwarf virus (Glais and Jacquot 2015), banana bunchy top virus (Kapoor et al. 2017), citrus yellow mosaic virus (Kumar et al. 2018), bean golden yellow mosaic virus, tomato mottle virus, tomato yellow leaf curl virus (Londoño et al. 2016; Wang and Yang 2019), milk vetch dwarf virus (Cao et al. 2020), and piper yellow mottle virus (Mohandas and Bhat 2020); and with RNAbased genomes such as little cherry virus-2 (Mekuria et al. 2014), plum pox virus (Zhang et al. 2014; Babujee et al. 2019), rose rosette virus (Babu et al. 2017), rice blackstreaked dwarf virus (Zhao et al. 2019), cucumber mosaic virus (Srivastava et al. 2019), maize chlorotic mottle virus (Jiao et al. 2019a), apple stem pitting virus (Kim et al. 2019), cucumber green mottle mosaic virus (Jiao et al. 2019b; Zeng et al. 2019), cucurbit yellow stunting disorder virus (Kalischuk et al. 2020), and peach latent mosaic viroid (Lee et al. 2020). RPA has also been successfully applied for detection of the potyviruses plum pox virus (Zhang et al. 2014), yam mosaic virus and yam mild mosaic virus (Silva et al. 2015), potato virus Y (Glais and Jacquot 2015; Babujee et al. 2019), and chilli veinal mottle virus (Jiao et al. 2020). The type of tissue used as viral sources in RPA assays include leaves, budwood, grape mealybugs, stems, petals, pollen/anthers, whole flowers and roots, but seeds haven't been reported for the assay. In this study, we designed specific primers based on $C P$ gene sequences of BCMV isolates to develop an RPA assay. RPA products can be analyzed by agarose gel electrophoresis or by using a lateral flow dipstick (LFD) assay that avoids the time and equipment required for electrophoresis (MileniaBiotec, Giessen, Germany). End-labeled RPA amplification products can be detected by LFD in 5 min. The main advantage of the new RPA-LFD assay described here is that the whole reaction process can be carried out in a non-laboratory environment after the nucleic acid sample is obtained.

The objectives of this study were to (i) develop primers and probe for specific detection of BCMV by RPA-LFD; (ii) evaluate the specificity of the assay against related potyviruses; (iii) compare the sensitivity of the new developed RPA-LFD assay with conventional PCR; (iv) evaluate the assay with different BCMV-infected legume species; (v) evaluate the assay in detecting seed-borne BCMV.

\section{Results \\ Establishment of RPA-LFD assay for the detection of BCMV}

To evaluate the simplicity and rapidity of RPA-LFD assay for the detection of BCMV in legume plants, BCMV-infected soybean samples exhibiting severe mosaic symptoms were collected from different experimental farms in Jiangsu Province, China. The cDNA synthesized from the total RNA of diseased soybean samples was used as template for PCR and RPA-LFD assays, with cDNA samples from the uninfected (healthy) soybean plants as negative controls. PCR results demonstrated that a 150-bp product corresponding to the partial BCMV CP gene was amplified from diseased soybean plants, but not from healthy soybean plants (Fig. 1a). Similarly, the RPA-LFD assay successfully detected $B C M V$ in the diseased plants using specific primers and a probe against the partial BCMV CP gene, and did not detect BCMV in uninfected plants (Fig. 1b), indicating that RPA-LFD can be used for the detection of BCMV in soybean plants.

RPA-LFD assay is more sensitive than conventional PCR in the detection of BCMV

To evaluate the sensitivity of the RPA-LFD assay, the detection limit of the RPA-LFD assay was evaluated by testing 10 -fold serial dilutions (starting from $4 \mathrm{ng} / \mu \mathrm{L}$ ) of cDNA samples derived from BCMV-infected soybean, and by comparing results with those of conventional PCR. RPA-LFD successfully detected BCMV even when cDNA samples was diluted $10^{5}$-fold (Fig. 2a). In contrast, the PCR assay detected BCMV in cDNA samples diluted up to $10^{2}$-fold (Fig. 2b). Thus, the RPA-LFD assay was 1000 times more sensitive than the PCR assay.

\section{Specificity of the RPA-LFD assay}

Symptoms of BCMV infection can resemble those of other potyviruses that occur in legume crops. Therefore, isolates of soybean mosaic virus (SMV), bean yellow mosaic virus (BYMV) and turnip mosaic virus (TuMV), all belonging to the genus Potyvirus, were selected to test specificity of the RPA-LFD assay. Isolates of SMV, 


\section{a}

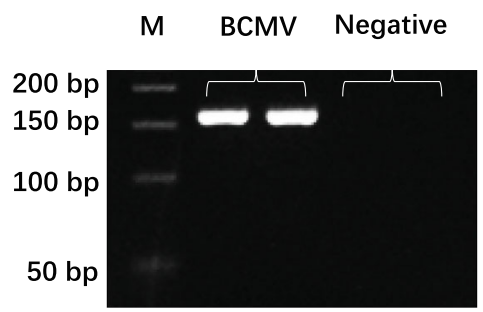

b

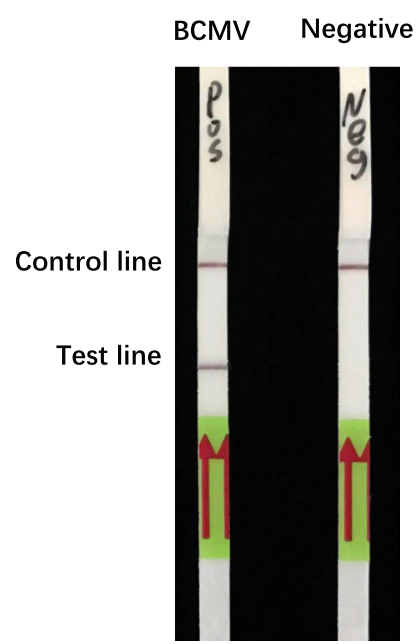

Fig. 1 Development of an RPA-LFD assay for the detection of BCMV from soybean plant tissues. a Detection of BCMV from BCMV-infected soybean plants by RT-PCR assay using BCMV-CP primers, with non-infected (healthy) plants as negative control. b Detection of BCMV from BCMVinfected soybean plants by RPA-LFD using BCMV-specific primers and probe, with non-infected healthy plants as negative control

TuMV and BYMV all consistently tested negative in both the RPA-LFD-based and PCR-based assays for BCMV (Fig. 3a, b).

\section{Evaluation of the RPA-LFD assay using soybean and adzuki bean plants}

To verify the effectiveness of the RPA-LFD method for detecting BCMV in legume plants, leaves of nine soybean (Glycine max) plants were manually-inoculated with sap from a BCMV-infected soybean plant. Untreated soybean plants served as negative controls. Two weeks later, all plants were sampled for RT, followed by PCR and RPA-LFD detection of BCMV. As expected, both RPA-LFD and PCR assay results showed that all diseased plants were positive for BCMV while all control plants were negative (Fig. 4a, b).

To further test the effectiveness of RPA-LFD in detecting BCMV in legume plants in the field, we collected 21 adzuki bean (Phaseolus angularis) samples from several regions of Jiangsu Province, China, including 16 suspected virus-infected and five symptomless ones. These were tested by PCR and RPA-LFD for BCMV. There were 16 positive plants among the 21 tested samples, as detected by both RPA-LFD and PCR assays (Fig. 4c, d). Detailed results of the detection analyses are provided in Table 1.

\section{Detection of seed-borne BCMV using RPA-LFD}

$\mathrm{BCMV}$ is seed-borne in many legumes. We tested the effectiveness of the RPA-LFD assay for detection of seedborne BCMV in adzuki beans. Total RNA was extracted from ten seeds derived from infected parental plants, and this was used as a template for RT, followed by RPA-LFD and PCR assays. Both assays detected BCMV in seeds (Fig. 5a, b). However, bands from the PCR assay were unclear when observed on an imager, because adzuki bean seeds contain large quantities of polysaccharides, proteins, secondary metabolites such as phenols and a fat content of up to $40 \%$. Polysaccharides and a

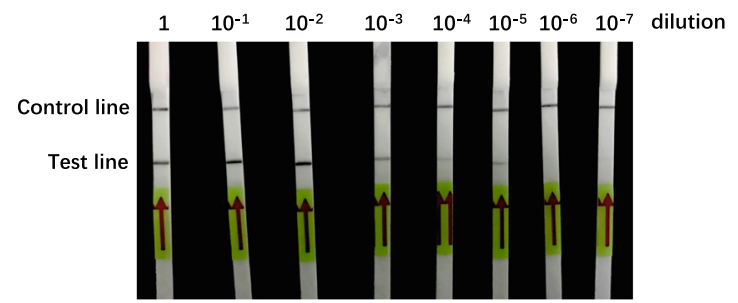

b

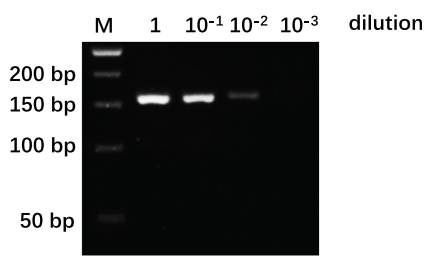

Fig. 2 Comparison of the sensitivity of RPA-LFD and PCR assay for the detection of BCMV. a Detection of BCMV from 10-fold serial dilutions of CDNA samples from BCMV-infected soybean by RPA-LFD. $\mathbf{b}$ Detection of BCMV from 10-fold serial dilutions of the same cDNA samples as in $\mathbf{a}$ by PCR assay 
a

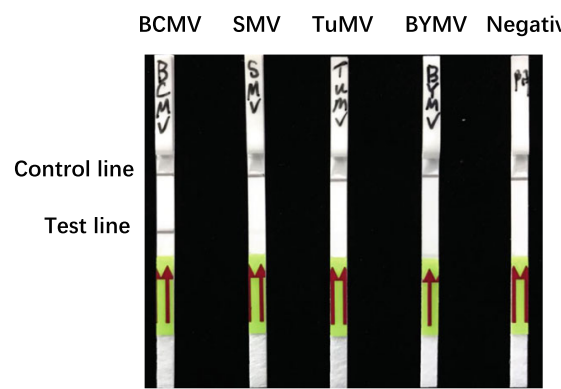

b

M BCMV SMV TuMV BYMV Negative

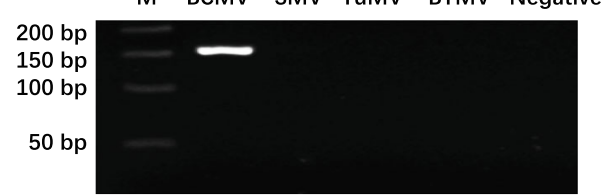

Fig. 3 Specificity of RPA-LFD assay for BCMV detection. a BCMV, SMV, TuMV and BYMV samples were detected by RPA-LFD assay using BCMVspecific primers and probe. b BCMV, SMV, TuMV and BYMV samples were detected by PCR using BCMV-CP primers. In RPA-LFD and PCR assays, the cDNAs from virus-infected soybean were used as templates, with cDNA from healthy plant as negative control

these other metabolites can inhibit the activity of many enzymes and therefore may interfere with PCR-based methods for BCMV detection. By contrast, using the same samples, we found the sensitivity of RPA-LFD to detect BCMV was 1000 times higher than that of the PCR method. The results of detection are read with a test strip, which is clear and intuitive. Therefore, when detecting BCMV in adzuki bean seeds, the RPA-LFD method was more sensitive and effective than the PCR.

\section{Detection of crude plant extract using RPA-LFD}

To further test the effectiveness of the RPA-LFD in detecting BCMV from the crude extract of plant samples, eight BCMV-infected soybean samples and four healthy samples were used. In all samples, $0.1 \mathrm{~g}$ of fresh leaves were ground with $1 \mathrm{~mL}$ of buffer solution, then were centrifuged and the supernatant was used immediately to perform the RPA-LFD experiment. RT-PCR assay was performed on the corresponding samples using purified RNA extracts. The results showed that the RPA-LFD method can detect BCMV directly from crude soybean extracts and that the test results were consistent with results of RT-PCR (Fig. 6a, b). The whole RPA-LFD process can be completed within 30 min. The RPA-LFD is also sensitive to detect BCMV from crude extract of soybean leaves. It is suitable for non-professional experimenters to rapidly and simply detect BCMV infected-plants in the field.

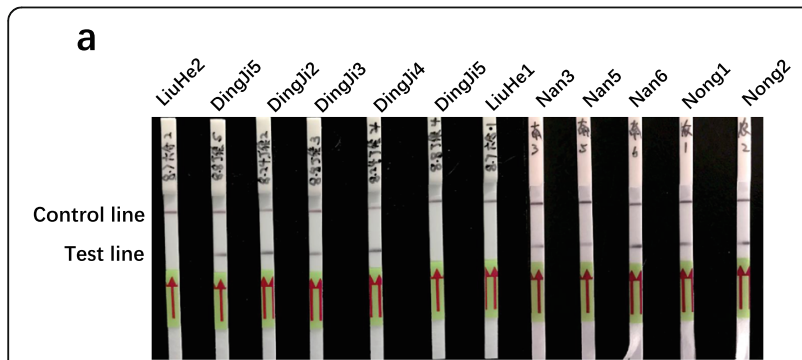

b

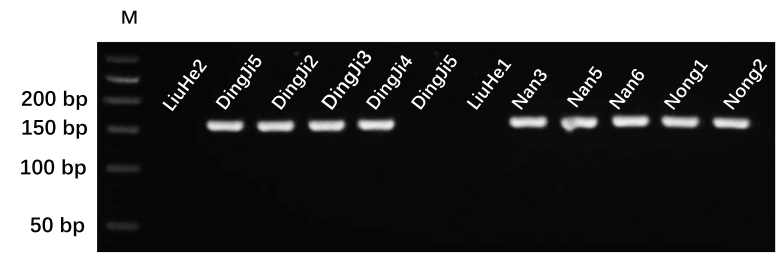

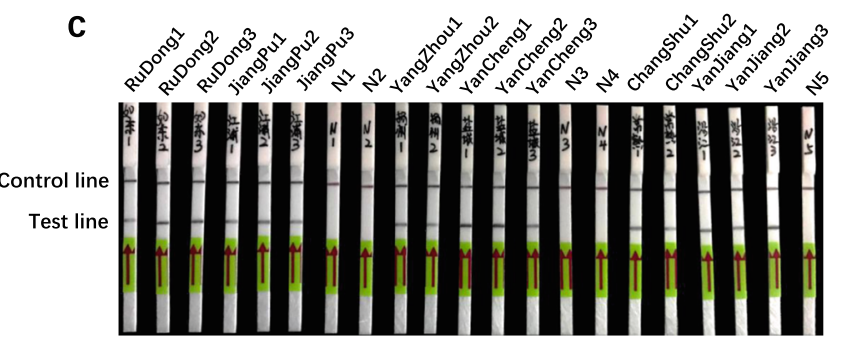

d

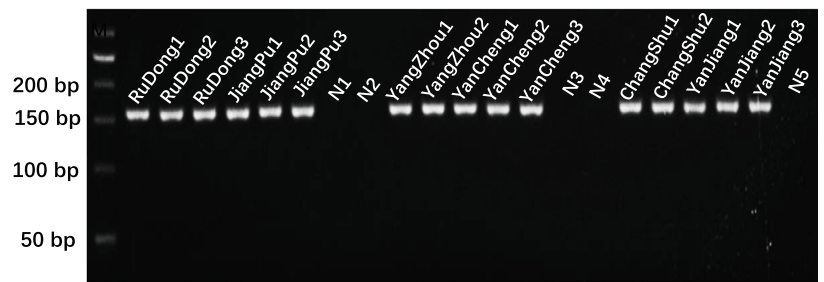

Fig. 4 Application of the RPA-LFD assay in BCMV-infected legumes. a Twelve suspected BCMV-infected soybean samples were detected by RPALFD assay. $\mathbf{b}$ The same soybean samples tested in a were detected by PCR method. $\mathbf{c}$ Twenty-one adzuki bean samples were tested by RPA-LFD. d The same adzuki bean samples used in c were tested by PCR 
Table 1 Detection results by RPA-LFD for BCMV in soybean and adzuki bean samples from different regions of Jiangsu Province,

China

\begin{tabular}{|c|c|c|c|c|c|}
\hline Leaf sample & Original host & Geographical origin $^{a}$ & BCMV-specific RPA-LFD assay & BCMV-specific PCR assay & Symptoms \\
\hline LiuHe 2 & Soybean & JAAS & - & - & Symptomless \\
\hline DingJi 5 & Soybean & JAAS & + & + & Mosaic and shrinking \\
\hline DingJi 2 & Soybean & JAAS & + & + & Mosaic \\
\hline DingJi 3 & Soybean & JAAS & + & + & Mosaic and shrinking \\
\hline DingJi 4 & Soybean & JAAS & + & + & Mosaic and shrinking \\
\hline DingJi 5 & Soybean & JAAS & - & - & Symptomless \\
\hline LiuHe 1 & Soybean & JAAS & - & - & Symptomless \\
\hline Nan3 & Soybean & JAAS & + & + & Mosaic and shrinking \\
\hline Nan5 & Soybean & JAAS & + & + & Mosaic and shrinking \\
\hline Nan6 & Soybean & JAAS & + & + & Mosaic \\
\hline Nong1 & Soybean & JAAS & + & + & Mosaic \\
\hline Nong2 & Soybean & JAAS & + & + & Mosaic \\
\hline RuDong1 & Adzuki bean & Rudong, Jiangsu, China & + & + & Mosaic \\
\hline RuDong2 & Adzuki bean & Rudong, Jiangsu, China & + & + & Mosaic \\
\hline RuDong3 & Adzuki bean & Rudong, Jiangsu, China & + & + & Mosaic \\
\hline JiangPu1 & Adzuki bean & Nanjing, Jiangsu, China & + & + & Mosaic \\
\hline JiangPu2 & Adzuki bean & Nanjing, Jiangsu, China & + & + & Mosaic \\
\hline JiangPu3 & Adzuki bean & Nanjing, Jiangsu, China & + & + & Mosaic \\
\hline N1 & Adzuki bean & JAAS & - & - & Symptomless \\
\hline N2 & Adzuki bean & JAAS & - & - & Symptomless \\
\hline YangZhou1 & Adzuki bean & Yangzhou, Jiangsu, China & + & + & Mosaic \\
\hline YangZhou2 & Adzuki bean & Yangzhou, Jiangsu, China & + & + & Mosaic \\
\hline YanCheng1 & Adzuki bean & Yancheng, Jiangsu, China & + & + & Mosaic \\
\hline YanCheng2 & Adzuki bean & Yancheng, Jiangsu, China & + & + & Mosaic \\
\hline YanCheng3 & Adzuki bean & Yancheng, Jiangsu, China & + & + & Mosaic \\
\hline N3 & Adzuki bean & JAAS & - & - & Symptomless \\
\hline N4 & Adzuki bean & JAAS & - & - & Symptomless \\
\hline ChangShu1 & Adzuki bean & Changshu, Jiangsu, China & + & + & Mosaic \\
\hline ChangShu2 & Adzuki bean & Changshu, Jiangsu, China & + & + & Mosaic \\
\hline YanJiang1 & Adzuki bean & Rugao, Jiangsu, China & + & + & Mosaic \\
\hline YanJiang2 & Adzuki bean & Rugao, Jiangsu, China & + & + & Mosaic \\
\hline YanJiang3 & Adzuki bean & Rugao Jiangsu, China & + & + & Mosaic \\
\hline N5 & Adzuki bean & JAAS & - & - & Symptomless \\
\hline
\end{tabular}

a JAAS: Jiangsu Academy of Agricultural Sciences

\section{Discussion}

We developed an RPA-LFD assay to detect BCMV from legume plants and compared outcomes with a conventional PCR assay. The RPA-LFD assay was 1000 times more sensitive than the PCR, and had no cross-reactivity with three other potyviruses. Reaction time of the RPALFD assay was less than $20 \mathrm{~min}$, compared with $150 \mathrm{~min}$ for the PCR assay using samples of the same target concentration. Detection of BCMV in adzuki bean leaves and seeds proved applicability of the RPA-LFD assay beyond soybean. RPA-LFD was able to detect BCMV from crude leaf extracts, without tedious extraction and purification of total RNA. This method is suitable for rapid on-site diagnosis.

Compared with other plant virus assays, the RPA-LFD method has the following advantages:

(1) Primer design is simple. Compared with the loopmediated isothermal amplification method (LAMP), a constant temperature amplification technology 


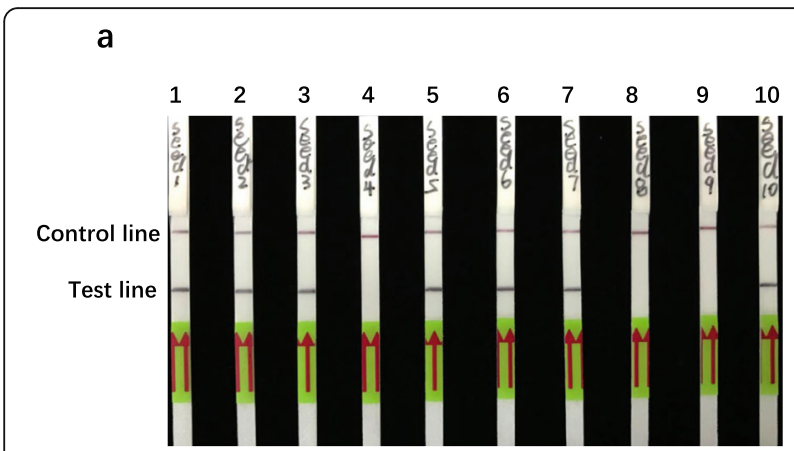

b

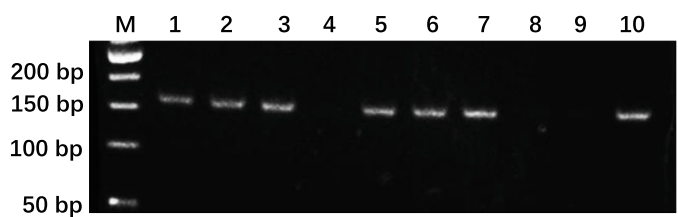

Fig. 5 Detection of BCMV in adzuki bean seeds using RPA-LFD and PCR. CDNA obtained from 10 adzuki bean seeds from infected parental plants were used as templates for detection of BCMV by both RPA-LFD (a) and PCR methods (b)

which requires a complex primer design, RPA-LFD detection requires only a pair of primers and one probe to complete amplification;

(2) It does not require thermal cycling instruments. The RPA-LFD isothermal amplification reaction can be achieved under isothermal conditions from $37^{\circ} \mathrm{C}-42^{\circ} \mathrm{C}$, requiring only a water heater and thermostat;

(3) The reaction time is only $15-30 \mathrm{~min}$;

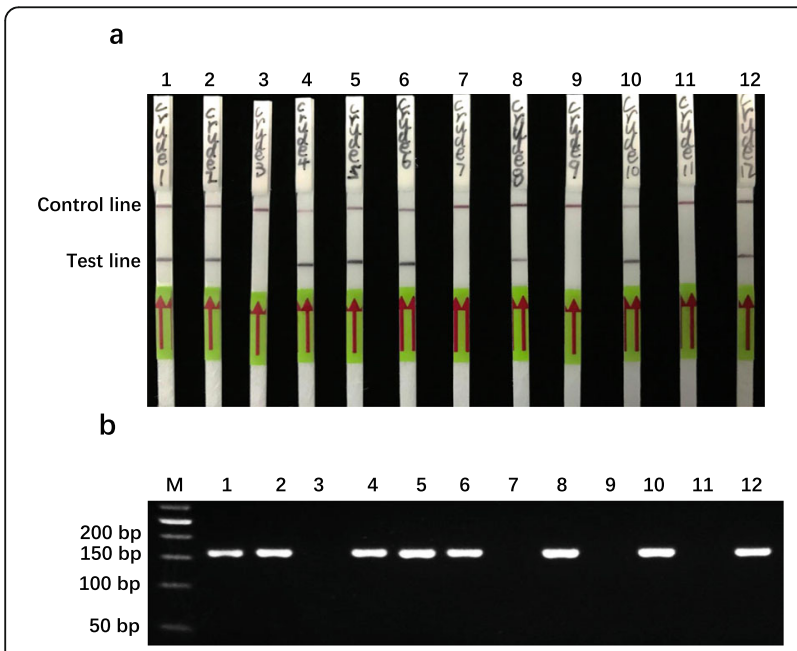

Fig. 6 Detection of BCMV in crude plant extracts by RPA-LFD. a RPA-LFD assay using crude sample extracts of soybean samples in the field, which were suspected to be BCMV-infected. $\mathbf{b}$ RT-PCR assay using purified RNA extracts from corresponding samples in a
(4) RPA combined with a lateral flow dipstick (RPALFD) avoids a gel electrophoresis step;

(5) It has high sensitivity and can directly detect BCMV in seeds. Although RT-PCR could detect BCMV in seeds, sensitivity was low. Polysaccharides, proteins and secondary metabolites in legume seeds may interfere with RNA extraction and inhibit subsequent PCR-based assays. As a result, no clear BCMV-CP gene bands were observed using gel imaging system, which may lead to false negatives. In contrast, RPA-LFD is more sensitive than PCR, and the results of detection are more clearly visualized without misjudgment;

(6) It was able to detect BCMV in soybean and adzuki bean.

Although RPA has clear advantages over PCR in diagnosis of plant viruses, a limitation is the cost. Cost of reagents per sample is much higher than the cost of a PCR. The authors believe that as RPA technology becomes more widely adopted, the cost per unit will eventually be closer to that of PCR reagents.

\section{Conclusions}

The RPA-LFD method for detecting BCMV established in this study is simple, specific and highly sensitive. It can detect BCMV in dry seeds and in different legume crops including soybean and adzuki bean. We believe that with the continuous development of RPA technology, it will play a wider role in the rapid diagnosis of BCMV and other viruses of concern in agriculture and elsewhere.

\section{Methods}

\section{Sources of plant samples}

All BCMV-infected legume plants including soybean (Glycine max) and adzuki bean (Phaseolus angularis) showing severe mosaic symptom were collected from different regions of Jiangsu Province, China. The positive control for the test is the confirmed BCMV source from the laboratory and the negative control is set as healthy soybean leaves. All samples were stored at $-80^{\circ} \mathrm{C}$ after PCR detection and sequence determination. The virus samples of SMV and BYMV were stored in our laboratory and TuMV full length cDNA infectious clone vector was kindly provided by Prof Aiming Wang (Agriculture and Agri-Food, Canada).

\section{RNA extraction, CDNA synthesis}

Total RNA of soybean and adzuki bean leaves and adzuki bean seeds was extracted using a Plant Total RNA extraction kit from Tiangen Biotechnology Co., Ltd.. The purity and yield of RNA extracts were measured by NanoDrop 2000C microvolume UV-Vis 
spectrophotometer. First-strand cDNA was synthesized from $1 \mu \mathrm{g}$ of total RNA in a $20 \mu \mathrm{L}$ volume using the PrimeScript $^{\text {m }}$ RT Master Mix Kit (TaKaRa, Dalian, China), according to the manufacturer's instructions. The cDNA was stored at $-20^{\circ} \mathrm{C}$.

\section{Crude sample extraction}

Approximately $100 \mathrm{mg}$ of fresh soybean leaf tissue was homogenized in a centrifuge tube with $1 \mathrm{~mL} 1 \times$ PBS buffer ( $\mathrm{pH} 7.4$ ) containing $2 \%$ Tween-20. The supernatant of crude extracts were performed reverse transcription immediately after centrifugation at $4{ }^{\circ} \mathrm{C}$.

\section{Detection of BCMV using RPA-LFD}

RPA primers were designed to target the partial BCMV $C P$ gene (An alignment of CPs from different strains of NCBI reference sequence) following the manufacturer's specific parameters (TwistDx, Cambridge, UK). RPA was carried out using the materials and protocol (TwistDx, Cambridge, UK) from the TwistAmp nfo kit. The RPA reaction was performed in a $50-\mu \mathrm{L}$ reaction volume containing $1 \mu \mathrm{L}$ of BCMV-infected soybean plant cDNA, $29.5 \mu \mathrm{L}$ rehydration buffer, $2.1 \mu \mathrm{L}$ of $10 \mathrm{mM}$ forward primer (RPA-BCMV-F:5' -TTAGATCATCTGTTGGAT TACAAGCCAGAACA-3'), $2.1 \mu \mathrm{L}$ of $10 \mathrm{mM}$ reverse primer (RPA-BCMV-R: $5^{\prime}$-CACCACACCATAAAGCCA TTCATCACAATTGA $-3^{\prime}$ ), $0.6 \mu \mathrm{L}$ of $10 \mathrm{mM}$ probe (BCMV-nfo-probe: [5'FAM] ACAAAGATGCAGTT TGAAATGTGGTACAAT [THF] CTGTGAAGGA AGAGTA [3'BLOCK]) and $2.5 \mu \mathrm{L}$ of $280 \mathrm{mM}$ magnesium acetate. All RPA samples were incubated at $37^{\circ} \mathrm{C}$ for $20 \mathrm{~min}$. For lateral flow analysis, with reference to the kit operation (Milenia Genline HybriDetect test strip, Germany), $5 \mu \mathrm{L}$ of RPA-amplified products were mixed with $100 \mu \mathrm{L}$ of assay buffer (HybriDetect assay Buffer) in a new reaction tube. Then the LFD strip was immersed into the mixture and incubated for $5 \mathrm{~min}$ at room temperature. A band with one visible line in the control area was considered as negative, and a band with two visible lines in both the control area and test area was considered as positive.

\section{Detection of BCMV using PCR}

The PCR reactions were performed using $10 \mu \mathrm{L} 2 \times$ Tap Master Mix (Dye Plus) (Vazyme Biothe, Nanjing, China), $0.2 \mu \mathrm{M}$ each of forward primer (BCMV-CP-F:5' -TTAG ATCATCTGTTGGATTGG-3') and reverse primer (BCMV-CP-R:5' -CACCACACCATAAAGCCATTC-3') and $1 \mu \mathrm{L}$ cDNA in a $20 \mu \mathrm{L}$ reaction volume. All samples were denatured at $95^{\circ} \mathrm{C}$ for $5 \mathrm{~min}$. Then 30 cycles were performed $\left(95^{\circ} \mathrm{C}\right.$ for $30 \mathrm{~s}, 58^{\circ} \mathrm{C}$ for $30 \mathrm{~s}$ and $72^{\circ} \mathrm{C}$ for 30 s), and the last step was $72^{\circ} \mathrm{C}$ for $10 \mathrm{~min}$. The obtained PCR product was separated on a $3 \%$ agarose gel. After staining with ethidium bromide, images were observed using a Bio-Rad Molecular Imager gel DOCXR system (Bio-Rad, Hercules, CA, USA).

\section{Specificity and sensitivity assay}

The specificity of the designed primers/ probe was tested using RPA-LFD, against other potyviruses infecting legume or no host-pathogen. A positive control is the cDNA from the BCMV-infected soybean samples and the negative control is the cDNA from healthy soybean plant. For the sensitivity assay, a series of 10 -fold dilutions (to $10^{5}$ ) of cDNA from $4 \mathrm{ng}$ were prepared in diethyl pyrocarbonate (DEPC)-treated water for RPA-LFD and PCR analysis using the RPA primers.

\section{Abbreviations \\ BCMNV: Bean common mosaic necrotic virus; BCMV: Bean common mosaic virus; BYMV: Bean yellow mosaic virus; CDNA: Complementary DNA; CP: Coat protein; LAMP: Loop-mediated isothermal amplification method; LFD: Lateral flow dipsticks; PBS: Phosphate buffer saline; PCR: Polymerase chain reaction; RPA: Recombinase polymerase amplification; RPA-LFD: Recombinase polymerase amplification combined with the lateral flow dipstick; RT- PCR: Reverse transcription-polymerase chain reaction; SMV: Soybean mosaic virus; TuMV: Turnip mosaic virus}

\section{Acknowledgements}

We thank Prof. Daolong Dou (Nanjing Agricultural University) and Dr. Feng Sun (Jiangsu Academy of Agricultural Sciences) for their valuable suggestions on this work, and Prof. Stephen J Wylie (Murdoch University, Australia) for critical reading of the manuscript.

\section{Authors' contributions}

XYC conceived the project. XYC and XHC supervised the work. JCQ performed most of the experiments with assistance from ZY, XC, DYS and HTC. All authors analyzed the data. JCQ and XYC wrote the manuscript. All authors read and approved the final manuscript.

\section{Funding}

This work was supported by the National Natural Science Foundation of China (31101411), National Key Research and Development Project (2016YFE0203800, 2018YFE0112200), the Key R \& D project of Jiangsu Province (BE2019376), National edible bean industry technology system (CARS-08-G15) and Jiangsu Agricultural Industry Technology System (JATS[2019]399). The research was carried out in the joint lab of China-AAFC for legume research in JAAS.

\section{Availability of data and materials}

Not applicable.

Ethics approval and consent to participate Not applicable.

\section{Consent for publication}

Not applicable.

\section{Competing interests}

The authors declare that they have no competing interests.

\section{Author details}

${ }^{1}$ Institute of Industrial Crops, Jiangsu Academy of Agricultural Sciences/ Jiangsu Key Laboratory for Horticultural Crop Genetic Improvement, Nanjing, Jiangsu 210014, People's Republic of China. ${ }^{2}$ Department of Horticulture, College of Horticulture and Plant Protection, Yangzhou University, Yangzhou, Jiangsu 225009, People's Republic of China. 'Beijing Plant Protection Station, Bejing 100029, People's Republic of China. ${ }^{4}$ Department of Plant Pathology, College of Plant Protection, Nanjing Agricultural University, Nanjing, Jiangsu 210014, People's Republic of China. ${ }^{5}$ Institute of Life Science, Jiangsu University, Zhenjiang, Jiangsu 212013, People's Republic of China. 
Received: 16 September 2020 Accepted: 4 January 2021

Published online: 02 February 2021

\section{References}

Babu B, Washburn BK, Miller SH, Poduch K, Sarigul T, Knox GW, et al. A rapid assay for detection of rose rosette virus using reverse transcriptionrecombinase polymerase amplification using multiple gene targets. J Virol Methods. 2017;240:78-84.

Babujee L, Witherell RA, Mikami K, Aiuchi D, Charkowski AO, Rakotondrafara AM, et al. Optimization of an isothermal recombinase polymerase amplification method for real-time detection of potato virus $\mathrm{Y} O$ and $\mathrm{N}$ types in potato. $J$ Virol Methods. 2019;267:16-21.

Cao Y, Yan D, Wu X, Chen Z, Lai Y, Lv L, et al. Rapid and visual detection of milk vetch dwarf virus using recombinase polymerase amplification combined with lateral flow strips. Virol J. 2020;17:102.

Cui XY, Shen L, Yuan XX, Gu HP, Chen X. First report of bean common mosaic virus infecting mungbean (Vigna radiata (Linn.) Wilczek.) in China. Plant Dis. 2014;98:1590.

Damayanti TA, Susilo D, Nurlaelah S, Sartiami D, Okuno T, Mise K. First report of bean common mosaic virus in yam bean [Pachyrhizus erosus (L.) urban] in Indonesia. J Gen Plant Pathol. 2008;74:438-42.

Drijfhout E, Slibernagel MJ, Burke DW. Differentiation of strains of bean common mosaic virus. Neth J Plant Pathol. 1978;84:13-26. https://doi.org/10.1007/ BF01978099.

Feng X, Poplawsky AR, Karasev AV. A recombinant of bean common mosaic virus induces temperature-insensitive necrosis in an I gene-bearing line of common bean. Phytopathology. 2014b;104:1251-7.

Feng X, Poplawsky AR, Nikolaeva OV, Myers JR, Karasev AV. Recombinants of bean common mosaic virus (BCMV) and genetic determinants of BCMV involved in overcoming resistance in common bean. Phytopathology. 2014a; 104:786-93.

Flores-Estévez N, Acosta-Gallegos JA, Silva-Rosales L. Bean common mosaic virus and bean common mosaic necrosis virus in Mexico. Plant Dis. 2003;87:21-5.

Flores-Estévez N, Silva-Rosales L, Acosta-Gallegos JA. First report of bean common mosaic necrotic virus infecting bean plants in Aguascalientes and Veracruz. Mexico Plant Dis. 2000;84:923.

Glais L, Jacquot E. Detection and characterization of viral species/subspecies using isothermal recombinase polymerase amplification (RPA) assays. In: Lacomme C, editor. Plant pathology. Methods in molecular biology, vol. 1302. New York: Humana Press; 2015. p. 207-25. https://doi.org/10.1007/9781-4939-2620-6 16.

Jang YW, Jo Y, Cho WK, Choi H, Yoon YN, Lim SM, et al. First report of bean common mosaic necrosis virus infecting soybean in Korea. Plant Dis. 2018; 102:2051.

Jiao Y, Jiang J, An M, Xia Z, Wu Y. Recombinase polymerase amplification assay for rapid detection of maize chlorotic mottle virus in maize. Arch Virol. 2019a; 164:2581-4.

Jiao Y, Jiang J, Wu Y, Xia Z. Rapid detection of cucumber green mottle mosaic virus in watermelon through a recombinase polymerase amplification assay. J Virol Methods. 2019b;270:146-9.

Jiao Y, Xu C, Li J, Gu Y, Xia C, Xie Q, et al. Characterization and a RT-RPA assay for rapid detection of chilli veinal mottle virus (ChiVMV) in tobacco. Virol J. 2020; 17:33.

Kalischuk ML, Roberts PD, Paret ML. A rapid fluorescence-based real-time isothermal assay for the detection of cucurbit yellow stunting disorder virus in squash and watermelon plants. Mol Cell Probes. 2020;53:101613.

Kapoor R, Srivastava N, Kumar S, Saritha RK, Sharma SK, Jain RK, et al. (2017). Development of a recombinase polymerase amplification assay for the diagnosis of banana bunchy top virus in different banana cultivars. Arch Virol. 2017:162:2791-6.

Kim NY, Lee HJ, Jeong RD. A portable detection assay for apple stem pitting virus using reverse transcription-recombinase polymerase amplification. J Virol Methods. 2019;274:113747

Kumar PV, Sharma SK, Rishi N, Ghosh DK, Baranwal VK. An isothermal based recombinase polymerase amplification assay for rapid, sensitive and robust indexing of citrus yellow mosaic virus. Acta Virol. 2018;62:104-8.

Lee HJ, Kim HJ, Lee K, Jeong RD. Rapid detection of peach latent mosaic viroid by reverse transcription recombinase polymerase amplification. Mol Cell Probes. 2020:53:101627.
Li Y, Cao Y, Fan Z, Wan P. Identification of a naturally occurring bean common mosaic virus recombinant isolate infecting azuki bean. J Plant Pathol. 2016; 98:129-33.

Li YQ, Liu ZP, Yang K, Li YS, Zhao B, Fan ZF, et al. First report of bean common mosaic virus infecting azuki bean (Vigna angularis Ohwi Ohashi) in China. Plant Dis. 2014;98:1017

Londoño MA, Harmon CL, Polston JE. Evaluation of recombinase polymerase amplification for detection of begomoviruses by plant diagnostic clinics. Virol J. 2016:13:48

McKern NM, Mink Gl, Barnett OW, Mishra A, Whittaker LA, Silbernagel MJ, et al. Isolates of bean common mosaic virus comprising two distinct potyviruses. Phytopathology. 1992;82:923-9.

Mekuria TA, Zhang S, Eastwell KC. Rapid and sensitive detection of little cherry virus 2 using isothermal reverse transcription-recombinase polymerase amplification. J Virol Methods. 2014:205:24-30.

Mink Gl, Silbernagel MJ. Serological and biological relationships among viruses in the bean common mosaic virus group. Arch Virol. 1992;5(Suppl 5):397-406. https://doi.org/10.1007/978-3-7091-6920-9_42.

Mohandas A, Bhat Al. Recombinase polymerase amplification assay for the detection of piper yellow mottle virus infecting black pepper. Virus Dis. 2020; 31:38-44.

Morales FJ. Common beans. In: Loebenstein G, Carr JP, editors. Natural resistance mechanisms of plants to viruses. Dordrecht: Springer; 2006. p. 367-82.

Piepenburg O, Williams CH, Stemple DL, Armes NA. DNA detection using recombination proteins. PLoS Biol. 2006;4(7):e204

Saiz M, Castro S, De Blas C, Romero J. Serotype-specific detection of bean common mosaic potyvirus in bean leaf and seed tissue by enzymatic amplification. J Virol Methods. 1994;50:145-54.

Saqib M, Jones RAC, Cayford B, Jones MGK. First report of bean common mosaic virus in Western Australia. Plant Pathol. 2005;54:563.

Saqib M, Nouri S, Cayford B, Jones RAC, Jones MGK. Genome sequences and phylogenetic placement of two isolates of bean common mosaic virus from Macroptilium atropurpureum in north-West Australia. Australas Plant Pathol. 2010;39:184-91.

Seo JK, Kang M, Shin OJ, Kwak HR, Kim MK, Choi HS, et al. First report of bean common mosaic virus in Cudrania tricuspidata in Korea. Plant Dis. 2015;99: 292.

Silva G, Bömer M, Nkere C, Kumar PL, Seal SE. Rapid and specific detection of yam mosaic virus by reverse-transcription recombinase polymerase amplification. J Virol Methods. 2015;222:138-44

Srivastava N, Kapoor R, Kumar R, Kumar S, Saritha RK, Kumar S, et al. Rapid diagnosis of cucumber mosaic virus in banana plants using a fluorescencebased real-time isothermal reverse transcription-recombinase polymerase amplification assay. J Virol Methods. 2019:270:52-8.

Wang TM, Yang JT. Visual DNA diagnosis of tomato yellow leaf curl virus with integrated recombinase polymerase amplification and a gold-nanoparticle probe. Sci Rep. 2019;9:15146.

Zeng R, Luo J, Gao S, Xu L, Song Z, Dai F, et al. Rapid detection of cucumber green mottle mosaic virus by reverse transcription recombinase polymerase amplification. Mol Cell Probes. 2019:43:84-5.

Zhang S, Ravelonandro M, Russell P, McOwen N, Briard P, Bohannon S, et al. Rapid diagnostic detection of plum pox virus in Prunus plants by isothermal AmplifyRP (R) using reverse transcription-recombinase polymerase amplification. J Virol Methods. 2014;207:114-20.

Zhao C, Sun F, Li X, Lan Y, Du L, Zhou T, et al. Reverse transcription-recombinase polymerase amplification combined with lateral flow strip for detection of rice black-streaked dwarf virus in plants. J Virol Methods. 2019;263:96-100.

Ready to submit your research? Choose BMC and benefit from:

- fast, convenient online submission

- thorough peer review by experienced researchers in your field

- rapid publication on acceptance

- support for research data, including large and complex data types

- gold Open Access which fosters wider collaboration and increased citations

- maximum visibility for your research: over $100 \mathrm{M}$ website views per year

At BMC, research is always in progress.

Learn more biomedcentral.com/submission 